\title{
JUSTICE FOR VICTIMS? - THE SENTENCING OF \\ PUBLIC TRUST FIGURES CONVICTED OF CHILD \\ SEXUAL ABUSE: A FOCUS ON RELIGIOUS LEADERS
}

\section{JAMIE MARTIN}

\begin{abstract}
Child sexual abuse has recently been recognized as being much more pervasive than was once thought. The author addresses the recent increase in awareness of child sexual abuse and in particular, he comments on sentencing in child sexual abuse cases. From a historical account of the crime, the author proceeds to narrow his focus to that of child sexual abuse committed by those in positions of trust, particularly religious figures. The author discusses the sentencing patterns of such offenders with an analysis of recent case law. He concludes by speculating on future sentencing trends with respect to child sexual abuse offenders generally.
\end{abstract}

On reconnait depuis peu que l'exploitation sexuelle des enfants est beaucoup plus répandue qu'on ne le pensait. L'auteur constate une sensibilisation récente à cet égard et se penche plus particulièrement sur les décisions rendues dans les cas de violence sexuelle perpétrée contre les enfants. L'auteur commence par effectuer l'historique de ce crime et concentre ensuite son attention sur les agressions sexuelles commises par les personnes qui occupent des postes de confiance, dans le domaine religieux surtout. L'auteur discute du type de sanctions imposées aux coupables et procède à l'analyse des cas récents de jurisprudence. Il conclut en formulant quelques suppositions sur les tendances futures des sentences prononcées contre les coupables d'agressions sexuelles contre les enfants.

\section{TABLE OF CONTENTS}

I. INTRODUCTION $\ldots \ldots \ldots \ldots \ldots \ldots \ldots \ldots \ldots \ldots \ldots$

II. RESEARCH METHODOLOGY - FRAMEWORK

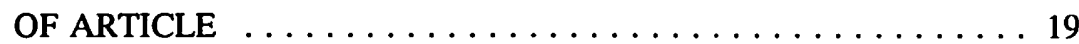

III. HISTORY OF CHILD SEXUAL ABUSE $\ldots \ldots \ldots \ldots \ldots \ldots \ldots 20$

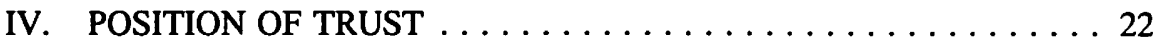

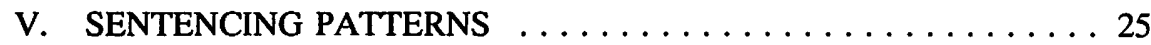

VI. PRINCIPLES AND FACTORS IN SENTENCING . . . . . . . 28

A. PRELIMINARY OBSERVATIONS -

LIMITED USE OF VENGEANCE . . . . . . . . . . . . . . . 29

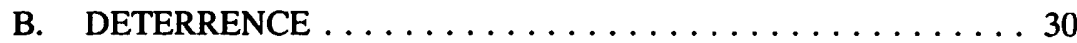

C. REHABILITATION OF THE OFFENDER $\ldots \ldots \ldots \ldots \ldots 31$

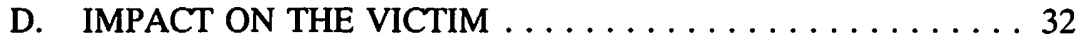

VII. SUMMARY AND CONCLUSIONS $\ldots \ldots \ldots \ldots \ldots \ldots \ldots \ldots 33$

A. FUTURE SENTENCING PATTERNS FOR

RELIGIOUS FIGURES - CHILD

SEXUAL ABUSE GENERALLY . . . . . . . . . . . . 34

\section{INTRODUCTION}

This article examines principles of sentencing employed by the courts in cases involving religious figures in positions of public trust who are convicted of child sexual 
abuse. Rix Rogers, a former special advisor to the Federal Minister of National Health and Welfare, in his report entitled "Reaching for Solutions" (submitted to the Federal Government in 1990) defines child sexual abuse in the following manner:'

...misuse of power by someone who is in authority over a child for the purposes of exploiting a child for sexual gratification. It includes incest, sexual molestation, sexual assault and the exploitation of the child for pornography or prostitution.

The Federal Commission on Sexual Offences Against Children, in a 1984 report, spoke of child sexual abuse as a "hidden yet pervasive tragedy that has damaged the lives of tens of thousands of Canadian children and youths." ${ }^{22}$ The Commission concluded that one in two females and one in three males at some time during their lives are the victims of one or more unwanted sexual acts. ${ }^{3}$

The national significance of the problem was recognized by former Ontario Supreme Court Justice Samuel Hughes who chaired a Royal Commission for the Government of Newfoundland and Labrador into the criminal justice system in that province. ${ }^{4}$ The

1 Canada, Report of the Special Advisor to the Minister of National Health and Welfare on Child Sexual Abuse in Canada (Ottawa: Minister of Supply and Services, 1990) (Chair: R. Rogers) at 19 [hereinafter Rogers].

$2 \quad$ Canada, Report of the Committee on Sexual Offences Against Children and Youth (Ottawa: Minister of Supply and Services, 1984) (Chair: R. Badgley) vol. 1 at 29 [hereinafter Badgley].

Rogers, supra note 1 at 11 writing six years later indicated that the incidence of child sexual is widespread and is still largely hidden, and that the problem permeates every segment of society and all communities.

See Badgley, ibid. Summary Report at 1.

Newfoundland, Royal Commission of Inquiry into the Response of the Newfoundland Criminal Justice System to Complaints (Newfoundland: Queen's Printer, 1991) (Chair: S. Hughes) at 459 [hereinafter Hughes Report]. The report was completed in 1991, however it was not released until April, 1992, pending the completion of the criminal cases involving Christian Brothers at the Mount Cashel Orphanage. Sentences for religious figures at Mount Cashel ranged from 1 to 12 years. In contrast, James Porter, a priest in the United States, was sentenced to 18 years in prison after pleading guilty to 27 charges of indecent assault and 14 other related charges. See "Priest gets 18 years" Globe and Mail (7 December 1993) A11.

It is interesting to note that a $\mathrm{CBC}$ movie entitled "The Boys of St. Vincent" was aired in most parts of Canada on December 6-7, 1992. The movie, although designed to be a fictional account of child sexual abuse and the clergy did rely extensively on events which occurred at Mount Cashel. The Ontario Court of Appeal, in December, 1992, ordered an injunction to prevent a viewing of the movie in Ontario and Montreal to protect the right of Christian Brothers to fair trials in that province. This decision is at [1992] O.J. No. 2703 (Q.L.).

Also see Toronto Star (10 February 1990) A15 in which nine high profile cases from all parts of the country were described.

Also see Rogers, supra note 1 at 53 in which he acknowledges that the cases in Newfoundland are the most highly publicized, but there have been cases in other Canadian provinces involving religious groups other than the Roman Catholic Church.

See "Ex Brother Acquitted of Reform School Sex" Toronto Star (8 August 1992) A8, in which 19 Christian brothers and twenty-nine individuals overall were charged with over 200 counts of child sexual abuse at two training schools in Ontario. These charges resurfaced in 1991 after an investigation in 1961 did not result in the laying of charges.

See L. Laurence, "An Uncelibate Sikh goes to jail" Alberta Report (17 February 1992) 30, for the case of Balrag S.S. in which the religious organization of which he was a member knew of his sexual 
Hughes report dealt extensively with problems arising from a criminal investigation of widespread child sexual abuse at the Mount Cashel orphanage in Newfoundland. The sentencing of religious figures at that institution by courts in Newfoundland have figured prominently in recent decisions of other jurisdictions and will be discussed throughout this article.

Current estimates suggest that there are over 400,000 child molesters in Canada. ${ }^{5}$ Religious figures as a specific class of offender represent a very small component of this group. In Canada, 56 priests or lay brothers have been convicted of sexual offences since 1983, while another 40 currently await trial. There are now 11,400 Roman Catholic priests in the country. Similarly, in the United States during the 1980s, 400 of the over 56,000 priests in that country were reported for child sexual abuse. The cases have cost the church $\$ 400$ million in settlements and other costs. ${ }^{6}$

This article will primarily focus on religious figures in the Roman Catholic Church who have been convicted of child sexual abuse. It should be made clear however at the outset, that an examination of religious figures as a specific class of offender, and in particular, the activities of individuals within the Roman Catholic Church, is not being undertaken to suggest that the Church has been totally irresponsible in discharging its responsibilities to provide spiritual guidance to its parishioners. Indeed, Rogers in his report acknowledges a number of initiatives undertaken by the church to address the problems associated with child sexual abuse. ${ }^{7}$ The commitment of the Roman Catholic Church to victims in particular is outlined in a report of the Canadian Conference of Catholic Bishops entitled "From Pain to Hope" which was released in June, $1992 .{ }^{8}$ Implicit in this report is support by the church of a position of zero tolerance for this type of crime.

On the other hand, it is reasonable to conclude that in responding to the illegal and immoral actions of a small minority of its leaders, the Church has not been consistent in

misconduct against teenage girls, but chose not to deal with the problem.

Also see "Hatfield Harassed Teenagers - Paper" Edmonton Journal, (10 November 1992) A7 for a discussion of the Toft case in New Brunswick. Although not a religious figure, Toft, a counsellor at a training school, was found guilty of thirty-five sex related charges involving young boys over a 20 year period. Toft was sentenced to thirteen years. Electronic media reports indicated that the New Brunswick Court was heavily influenced by the sentences imposed by Newfoundiand courts involving Mount Cashel. The activities of the training school are now the subject of a public inquiry initiated by the New Brunswick government.

The most high profile case in terms of an individual's position within the Church involved Bishop Patrick O'Connor of British Columbia. Bishop O'Connor was charged with 4 counts of indecent assault on young girls. In December, 1992, the trial judge issued a stay of proceedings owing to an improper use of prosecutional discretion in withholding documents from defence counsel. See $R$. Sudlow, "Bishops Sex Charges stayed because of Crown's conduct" Edmonton Journal (8 December 1992) A3.

$5 \quad$ R. Gillespie, "Average Offender Just Good Old Mr. Everyman" Vancouver Sun (15 June 1992) A4.

- T. Ford, "60s Sexual Revolution Has Only Brought New Problems" Edmonton Journal (14 February, 1993) A13.

7 Rogers, supra note 1 at 53. The author notes a number of initiatives taken by different religious denominations including educational materials by the Mennonite and Anglican Churches, and training projects in a number of provinces for Church leaders.

8 Canadian Conference of Catholic Bishops, From Pain to Hope (Ottawa: Concacan Inc., 1992). 
accommodating the needs of its parishioners. Well known criminal lawyer Edward Greenspan, writing prior to the substantial increase in prosecutions of religious leaders, concluded that the actions of church leaders has contributed to an "air of mistrust" by the public with respect to the class of offender (i.e. religious figures) and to the institution (i.e. the Church). The breach of trust which was committed was viewed as a serious aggravating factor in the overall sentencing process. ${ }^{9}$ It could be suggested that in the case of religious figures, there has been a breach of secular and moral laws which arguably sets this particular class of offender apart from others in a position of trust. In a recent decision of the Alberta Court of Appeal, obiter comments clearly indicate that "a religious leader who abuses trust is more blameworthy than a parent."10 The actions of religious figures, it could be argued, represents a significant breakdown in moral authority which I maintain has to be considered in the overall sentencing process.

Other factors, notably deterrence and denunciation, are also important in the sentencing process for religious figures and will be discussed later in the article. On the denunciation principle in particular, it will be argued that the media's shaping of public opinion is an important part of the sentencing process. ${ }^{11}$

\section{RESEARCH METHODOLOGY - FRAMEWORK OF ARTICLE}

The approach taken in this article was essentially to review over 25 sentencing judgments in six Canadian jurisdictions (NFLD, NS, ONT, AB, BC, NWT) and to examine the major reports prepared by government and the Church which provide interesting observations on the problem of child sexual abuse generally, and in particular when it is committed by religious figures.

The offences to be examined principally include the former offence of indecent assault which was replaced in 1983 by the offence of sexual assault. Sexual assault is presently s. 271 of the Criminal Code which carries a maximum period of imprisonment of 10 years. ${ }^{12}$ There are of course a number of other sexual offences against children, most of

See E. Greenspan, "Decisions on Sentencing" (1987/88) 30 Crim. L.Q. 148 at 153. Greenspan reviewed 3 cases in Newfoundland and Ontario involving religious figures. These include: Bennett, infra note 34; Crampton, infra note 34; and $R$. v. Hoskins (1987), 2 W.C.B. (2d) 23 (Nfld. C.A.).

Also see Rogers, supra note 1 at 52 in which the author acknowledges that the church as an institution was held in such high esteem, and is now being criticized for having "on occasion allowed the sexual abuse of children to continue as a horribly dark secret."

II' R. v. Balraj S.S. (15 September 1992), No. 13184 (Alta. C.A.) [unreported] at 2. Also see L. Laurence, supra note 4 for an account of public reaction to the trial at the Court of Queen's Bench.

"See a number of clippings which inevitably shape public opinion, "Oblate Brother Shocks Court with Guilty Pleas on charges of Gross Indecency to Natives" Vancouver Sun (3 April 1991) B1.

"Priests Sentence for Molesting Boys Called Too Lenient" Vancouver Sun (29 June 1991) A9.

"Mennonite Pastor Guilty of Assaulting Teenage Girls" Vancouver Sun (9 November 1991) A3.

"Pastor Guilty of Sex with Teenager" Calgary Herald (4 June 1991) B2.

For an interesting academic commentary on the role of the media and in particular how it impacts the reporting of crime see R. Ericson, P. Baraneck \& J. Chan, Representing Order: Crime, Law, and Justice in the News Media (Toronto: University of Toronto Press, 1991). 
which were created in 1988, such as sexual interference (s. 153) and invitation to sexual touching (s. 152). Although important, they do not figure prominently in this article. ${ }^{13}$

The balance of this article will therefore seek to

- provide a brief historical background of child sexual abuse in Canada from the perspective of the church, society, and the courts;

- define the elements considered important by the courts to conclude that an individual is in a position of trust, and illustrate by using individual case studies;

- identify the sentencing patterns of the courts in cases of child sexual abuse which involve religious figures;

- $\quad$ assess the various principles and factors considered by the Court in making its final determination on sentencing; and,

- finally provide some observations on where changes in sentencing patterns may occur in the future.

\section{HISTORY OF CHILD SEXUAL ABUSE}

A handbook prepared for the Federal Department of Justice on Canada's Law on Child Sexual Abuse provides relevant details on the history of the problem. ${ }^{14}$ In particular, the author notes that the issue of child rape was not separated from church law until the 13th century when it became a misdemeanour (not a felony) for a man to rape a female under the age of 12. The significance of the offence in being a misdemeanour is that more lenient dispositions were imposed by the courts. Generally misdemeanour offences are punishable by fine, penalty, forfeiture, or imprisonment other than in a penitentiary. ${ }^{15}$

Child sexual abuse became an issue in the 19th century. The focus was however on reforming the perpetrator as opposed to assisting the victim. There was a general reluctance to believe the testimony of children and this was especially relevant when allegations were made by children against community figures and those in a position of trust. $^{16}$

13 For the new sexual offences against children see R.S.C. 1985 (3d Supp.), c. 19. For a detailed list of the 16 sexual offences that can be committed against children see M. Wells, Canada's Law on Child Sexual Abuse: A Handbook (Ottawa: Communication and Public Affairs; Department of Justice, 1990) at 14. They include for example: Sexual Interference (s. 151), an offence in which the maximum penalty is 10 years if the Crown prefers to go indictable, and s. 152., Invitation to Sexual Touching with similar penal sanctions to Sexual Interference.

it See Wells, ibid.

is For a good discussion of the distinction between misdemeanour and felony offences see R. Salhany, Canadian Criminal Procedure, 5th ed. (Aurora: Canada Law Book Inc., 1989) at 1 and also D. Stuart, Canadian Criminal Law, 2d ed. (Toronto: Carswell, 1987) at 46. Wells, supra note 13 at 90. 
In the 1970s, child sexual abuse emerged as an emotional public issue. Rogers attributes this to two factors: (i) Provincial child abuse legislation developed in the 1960s which placed a duty on individuals to report cases of child sexual abuse; and (ii) the activities of the Women's Movement, and in particular the declarations of adult survivors of child sexual abuse. ${ }^{17}$ Rogers concedes that the problem has become more complicated in recent years with multiple victims and offenders, as opposed to isolated incidents involving a single individual within a family context.

Government response, particularly at the national level, as previously noted, was to establish the Badgley Commission, introduce legislative amendments, and appoint a special advisor to review longer term programming initiatives. The legislation, which became effective in January 1988, contained three elements which helped to stimulate increased prosecutions of child sexual abusers. The three principal elements included:

- the removal of the doctrine of recent complaint, in which the Court is required to question the testimony of a sexual abuse victim who did not complain to someone immediately after the occurrence of the offence;

- the removal of the requirement of corroboration (i.e. support evidence of child victim or the victim's testimony which was necessary to convict an accused); and

- the establishment of a number of new child sexual abuse offences. ${ }^{18}$

For its part, the Church has been viewed by many segments of society as lacking the appropriate initiative to recognize the severity of the problem. In particular, society generally felt that the Church contributed to the magnitude of the problem through a process of denial. One commentator noted that allegations of priests' molestation of children took place as far back as the 1960s. Instead of dealing with the problem, the Church actively engaged in a policy of transferring priests from parish to parish or simply allowing them to remain at the Church. ${ }^{19}$ The view of the Church is perhaps best reflected by a statement of the Superior General of the Basilican order following the

Rogers, supra note 1 at 20. An example of duty to report legislation is the Child Welfare Act, R.S.A. 1980 c. C-8, s. 3.

18 Wells, supra note 13 at 16-17. Recent cases of the Supreme Court of Canada confirm a relaxation of the evidentiary requirements for children at sexual abuse trials. See $R$. v. Khan (1990), 59 C.C.C. (3d) 92 at 102 dealing with the hearsay rule in which a child's statement to her mother about an alleged sexual abuse by a doctor was admitted into court through the mother.

Also see $R$. v. W.(R.), [1992] 2 S.C.R. 122 which points to the validity of a child's evidence even where key parts of the evidence is forgotten.

Also see R. v. B.(G.) (1990), 56 C.C.C. (3d) 200 at 219 (S.C.C.) in which Wilson J. suggested that the judiciary take a "common sense approach when dealing with the testimony of young children and not impose the same exacting standard on them as it does on adults."

Also sec Bala Nicholas, "Criminal Code Amendments to Increase Protection to Children and Women: Bills C-126 and C-128" (1993) 21 C.R. (4th) 365 for a discussion of further amendments to the Criminal Code which came into effect on August 1, 1993.

19 See K. Donovan, "How Catholic Church Turned Blind Eye to Child Sex Abuse by Priest" Toronto Star (10 February 1991) Al. 
conviction of a Roman Catholic Priest (Whyte) in Calgary on 18 sex related charges against young boys over a period of 20 years. This senior official in explaining why the Church failed to deal with allegations against the offender some 12 years earlier concluded that sexual assaults committed by priests were "isolated moral failures, ${ }^{, 20}$ thereby implying that no legal wrong had been committed. This case will be explored later in the article.

One can only speculate as to the reasons for the Church's position. It may, for example, be attributable to the high esteem in which it was held by the public. Moreover, it may have also been concerned about its own self image and thereby actively avoided potentially damaging civil and criminal litigation which would have been costly in terms of its financial resources and personnel levels. ${ }^{21}$ Whatever the reasons for the Church's inaction, it now recognizes the weaknesses in its previous approach to the problem. In the recent report of the Canadian Conference of Catholic Bishops, the Church acknowledges the "conspiracy of silence" which existed over the years. This revised position was summarized in a statement by the Roman Catholic Church: ${ }^{22}$

The ideal breeding ground for the development and repetition of child sexual abuse is a general conspiracy of silence, motivated by the fear of scandal and of major repercussions for the institutions directly or indirectly concerned.

\section{POSITION OF TRUST}

The Badgley report estimated that approximately one in four assailants is a family member or a person in a position of trust. ${ }^{23}$ It is therefore important for the purposes of this article to define a position of trust and to consider arguments to include religious figures in such a category. The precise definition of position of trust is not found in statute, in particular the Criminal Code; however, the common law does provide some direction.

Presently, s. 153 of the Criminal Code contains an offence (sexual exploitation) which prohibits a person in a position of trust from exploiting young persons in a sexual manner. The offence is largely designed to cover situations where young people are exploited because they are in a position of dependence, or where the accused is in a position of trust. These cannot be seen as distinct possibilities since individuals occupying positions of trust frequently create situations through which a dependency relationship is established and sustained.

G. Legge \& L. Church, "Priest's Victims Get Apology" Calgary Herald (19 January 1990) A1, A2. "Uneasy Times for Todays Priests" Toronto Star (23 March 1991) A7 - church officials explain that a decline in vocations to the priesthood is attributable to the revelations of widespread child sexual abuse, which has affected their esteem with the public. This essentially confirms the church's suspicions of the 1960s.

Canadian Conference of Catholic Bishops, supra note 8 at 22.

Badgley, supra note 2, Summary Report at 2. 
The section of the Code does not, however, provide any direction as to who occupies a position of trust. Martin's Annual Criminal Code does recognize a list of individuals who could be considered in such a position, and in doing so affirms the categories developed by the Badgley Commission. ${ }^{24}$

The list established in Badgley was not meant to be exhaustive. Religious figures were not specifically identified, however it can be inferred that the scope of the duties assigned to religious figures, such as teaching and counselling, could easily place them in one of the listed categories. ${ }^{25}$ Furthermore, in the case of the brothers at the Mount Cashel orphanage in Newfoundland, the religious figures were acting in loco parentis (in the place of a parent). The courts in focusing on this position of trust concluded that the Mount Cashel brothers were exercising "total control" over the boys. This was viewed as a significant aggravating factor in sentencing. ${ }^{26}$

The Badgley report is instructive in terms of defining whom amongst society may occupy a position of trust. The courts however, have provided more specific direction on the elements which should be met in order to establish a position of trust. This issue has normally arisen in civil litigation when the establishment of a fiduciary relationship is a central issue. A fiduciary relationship is accompanied by the highest standard of duty implied by law. It is submitted that the components required to establish a fiduciary relationship in civil matters are helpful in ascribing general characteristics to individuals in a position of trust for criminal proceedings.

McLachlin J. in a recent case, Norberg v. Wynrib, outlined three characteristics of a fiduciary relationship which have been established by the Supreme Court of Canada. They are:

i. the fiduciary has scope for the exercise of some discretion of power;

ii. the fiduciary can unilaterally exercise that power or discretion to affect the beneficiary's legal or practical interests; and

iii. the beneficiary is pecuniarily vulnerable or at the mercy of the fiduciary holding the discretion of power. ${ }^{27}$

Martins Anmual Criminal Code 1992 (Aurora: Canada Law Book, 1991) at CC/211 (synopsis). R.S.C. 1985 (3d Supp.) c. 19, s. 1.

See Badgley, supra note 2, vol. 1 at 57-59 in which 14 categories of individuals are listed as being in positions of public trust.

See for example, Wells, J. in R. v. Ralph (1992), 94 Nfld. \& P.E.I.R. and 298 A.P.R. 175 at 179 (Nfld. S.C.T.D.) (this case was appealed further and the sentence increased at [1993] N.J. No. 46 (Q.L.) (Nfld. S.C.A.D.); Wells J. in R. v. Thorne (1991), 92 Nfld. \& P.E.I.R. and 287 A.P.R. 310 at 315 (Nfld. S.C.T.D.); and Barry J. in R. v. Kenny, [1992] N.J. No. 118 (QL) (Nfld. S.C.T.D.) [hereinafter Kenny].

Norberg v. Wynrib (1992), 92 D.L.R. (4th) 449 at $488-89$ (S.C.C.). 
In Norberg v. Wynrib, the fiduciary relationship or a "relationship of trust" ${ }^{28}$ as McLachlin J. described it was between a doctor and a patient. That relationship was breached and therefore damages were awarded. McLachlin J. emphasized however that imbalance of power alone is insufficient to establish the fiduciary relationship. It must be accompanied by the potential for interference with a legal or non-legal interest. ${ }^{29}$

How can these arguments concerning the existence of a fiduciary relationship be applied to a discussion of criminal law principles, and in particular, the sentencing of religious figures convicted of child sexual abuse? One authority in the United States clearly places the clergy and parishioners in a fiduciary relationship. The author notes that parishioners place their trust and confidence in the clergy who in turn, accept that trust and place themselves in a position to exercise unique influence over individuals. ${ }^{30}$ The author outlines a number of factors which provide an opportunity for clergy to exploit individuals and breach their fiduciary obligation. These include:

- $\quad$ parishioners are easy prey for the unscrupulous;

- the absence of clear boundaries to delineate priestly and other duties;

- unlimited access to the homes and lives of the parishioners; and

- the absence of supervision and the relative autonomy of many clergy.

These factors, the author concludes, allow the perpetrator to take advantage of these opportunities and develop a pattern of victimization. ${ }^{31}$ These factors are quite evident in the case law in Canada and elsewhere, in terms of allowing religious figures in a position of trust to establish relationships that create a situation of dependency and control through which severe breaches of moral and secular law result.

The sordid fact patterns are often times similar and frequently involve acts of physical violence and mental suffering by the victim, and are clearly not unique to a particular province or community within Canada. Two cases involving priests, one in Newfoundland, the other in Alberta, illustrate this point. The case of $R$. v. Hickey in Newfoundland in 1988 involved a priest who pleaded guilty to 20 counts of sexual related offences committed against boys over a 17 year period. The individual used his position as parish priest to create a situation where exploitation of children could occur. The individual became extensively involved with young people, having served in such capacities as the first president of the Association of Youth Serving Agencies, the Coordinator of a youth

Ibid. at 495 .

$29 \quad$ Ibid. at 501 .

3) E. Cruz, "When the Shepherd Preys on the Flock: Clergy Sexual Exploitation and the Search for Solutions" (1991) 19 Fla. St. U.L. Rev. 499 at 513. 
rally for a royal visit in 1983, and chaplain in an all boys' school in the capital city, St. John's. The individual pleaded guilty and received a sentence of five years. ${ }^{32}$

Similarly, the case of $R$. v. Whyte in 1990 in Alberta demonstrates the way in which a situation of exploitation can be established. The individual was a teacher, counsellor and parish priest. These positions, the Court heard, were used to establish a special and close relationship with the parents whose sons were later assaulted. The court noted that this "preying" relationship continued over many years. The individual pleaded guilty to 19 counts of sexual offences, most of which included the former offence of indecent assault, which carried maximum imprisonment of 10 years. The individual was sentenced to four years by the Alberta Provincial Court. ${ }^{33}$ There are numerous other cases which clearly illustrate ways in which positions of trust were used to create situations in which sexual exploitation of children, many of whom were boys, could occur. ${ }^{34}$

Religious figures, in exercising considerable power and control over vulnerable young persons, clearly violated the position of trust which they established. While the presence of a position of trust is viewed in virtually all cases by the courts to be a significant aggravating factor in sentencing, there are a number of other issues and principles which are influential. The balance of this article will address these issues.

\section{SENTENCING PATTERNS}

Sentencing, in theory at least, is premised on the individual circumstances of each case, with a specific focus on the offence, offender, and victim. In practice however, it is possible to glean trends in sentencing based on a particular offence and a particular offender. Often sentencing will reflect the morals of society, and in particular, the public profile of a specific issue. For example, in the early 1980s, when the incidence of child sexual abuse generally was on the rise, there were only isolated cases involving religious figures. It was therefore not uncommon for the courts to impose a suspended sentence with probation. On the other hand, as offences involving high profile religious figures

32 R. v. Hickey (1988), 74 Nfld. \& P.E.I.R. and 231 A.P.R. 70 (Nfld. Prov. Ct.) [hereinafter Hickey]. Also see M. Harris Unholy Orders (Markham: Penguin Books, 1990) at 1-19. Also see Toronto Star (10 February 1990), supra note 4 A15.

33 R. v. Whyte (15 May 1987) (Alta. Prov. Ct.) [unreported] [hereinafter Whyte]. Also see Toronto Star (10 February 1990), supra note 4 A15, and Calgary Herald, supra note $20 \mathrm{A1}$, A2 for reaction to sentencing. In 1989, the Roman Catholic Diocese of Calgary established an advisory committee on sexual assault headed by the Archbishop. See "Priest Charged with Sexual Assaults" Edmonton Journal (23 January 1994) A5. This article discusses recent charges laid against a priest in Calgary in January 1994 following allegations that he sexually assaulted six females between 1960 and 1988 . See $R$. v. Bennett (1990), 83 Nfld. \& P.E.I.R. and 260 APR 182 at 187 (Nfld. S.C.T.D.). Individual held to be in position trust as priest, boy scout leader and as friend of the families whose children he abused.

See $R$. v. Crampton (1987), 22 O.A.C. 47 at 50 (Ont. C.A) [hereinafter Crampton]. The court was heavily influenced by testimony from parents of victims on the trust and the esteem in which the priest was held by the parents.

See $R$. v. Monaghan, [1988] B.C.J. No. 2582 (Q.L.) (B.C.C.A.) [hereinafter Monaghan]. On appeal the 81 year old priest put forward extensive community involvement to have a sentence of 4 years reduced. The appeal was dismissed. 
were increasing throughout the $1980 \mathrm{~s}$, the sentencing patterns changed to require a virtual period of incarceration. This trend is not markedly different compared with sentences imposed on other individuals committing major sexual assaults against children. This article, however, will focus on the rationale supporting these two extremes of sentencing within a short period of time for this particular category of offender (i.e. religious figures).

In 1988 for example, the Crampton case in Ontario involved the trial judge imposing a suspended sentence with three years probation. ${ }^{35}$ This type of sentence was not uncommon elsewhere where religious figures were involved and indeed the circumstances surrounding such a disposition by courts in some Provinces have been quite unusual. ${ }^{36}$ The sentence in Crampton was later reversed by the Court of Appeal and a period of eight months incarceration was ordered with the probationary period being maintained.

The Badgley Commission, in its review of the sentencing of child sexual abusers, points out that a suspended sentence with probation is often imposed when the court considers the accused as unlikely to commit further similar offences and will therefore benefit from the conditions of probation. ${ }^{37}$ Clayton Ruby, in his treatise on sentencing, concluded that suspended sentences with probation are useful in cases that do not require a period of incarceration for deterrence or denunciation. ${ }^{38}$

Historically, it could be argued that when religious figures have been convicted of child sexual abuse, the courts have been prepared to accept the Church's commitment to rehabilitate their members where possible, or to place them in jobs which would not allow them to exploit children. It should be noted that the Church has access to specialized treatment programs in major centres in Canada and the United States. ${ }^{39}$ It could therefore be argued that the imposition of a suspended sentence with probation would allow these religious figures to obtain treatment, at little or no cost to society, which arguably may

\section{See Crampton, ibid.}

See Hughes Report, supra note 4 at 156-161 in which reference is made to a 1979 unreported decision of the Nfld. Provincial Court (Kelly), in which the accused was given a suspended sentence and 2 years probation for ten charges of sexual offences against young boys. Former Justice Hughes referred in particular to the unusual circumstances surrounding the sentencing process which included calls being made by the Defence Lawyer to the Minister of Justice.

Similarly Harris, supra note 32 at 204 describes evidence submitted to the Hughes inquiry that the Bishop visited the sentencing judge a couple of days prior to the decision being made to discuss the range of sentencing alternatives for one of his clergy. Harris at 203 refers to accusations made by the defence lawyer that the Crown attorney had abused his prosecutorial power by allowing the charges to proceed. Reference was made, according to the Crown prosecutor in testimony before the Hughes Inquiry, to a 1975 case in which three Irish Christian Brothers had kept a promise to receive psychiatric treatment in lieu of having sexual assault charges laid against them.

See Badgley, supra note 2 vol. 2 at 812.

C. Ruby, Sentencing, 3d ed. (Toronto: Butterworths, 1987) at 231.

K. Donovan, "Bishops Hope New Guidelines Will Avert Abuse" Toronto Star (11 February 1990) A1, A14 describes Southdown Institute located in Aurora Ont., a specialized treatment centre for religious professionals including priests, brothers and nuns.

See also "Priests in Treatment" Evening Telegram (8 June 1993) 21 in which Rev. Joseph Schner in responding to two elderly priests from Saskatchewan undergoing treatment in the United States concluded at a news conference, "[w]e are a sinful church. If anybody wants any proof of it, we have that." 
have influenced the courts determination. It is debatable however, whether many of these offenders, most of whom are homosexual paedophiles, would be able to obtain treatment that would cure their illness and therefore ensure that the protection of the public, an overriding objective of the sentencing process, would be met.

It is clearly beyond the scope of this article to fully assess the merits of this argument. I believe it is simply too convenient to attribute the actions of the religious figures to sexual desire. It may be more appropriate to focus on the abuse of power which appears to be inherent in many parishioner-clergy relationships. What seems clear however, is that there has been an increasing reluctance by the public to accept the Church's commitment to treat these offenders, and to later minimize their involvement with society. The court therefore has exercised its responsibility to ensure that the protection of the public is reflected in the sentencing process.

It appears that as the incidence of child sexual abuse committed by religious figures increased and public outrage escalated, the patterns in sentencing had to change. Rogers noted that individuals in society were traumatized to learn that "some of our most trusted adults including...clergy have been victimizing children." ${ }^{140}$ Accordingly, Ruby's analysis would lead us to conclude that the effects of deterrence and denunciation overrode the potential to rehabilitate offenders which is inherent in a suspended sentence with probation.

A shift by the courts in sentencing religious figures convicted of child sexual abuse to a certain period of incarceration, started by the Crampton decision in Ontario, has been followed by the Courts of Appeals in a number of other Canadian jurisdictions, notably British Columbia, ${ }^{41}$ Newfoundland, ${ }^{42}$ Alberta, ${ }^{43}$ and Nova Scotia ${ }^{44}$ and a lower court in the Northwest Territories. ${ }^{45}$

The Alberta Court of Appeal, in a recent case, R. v. A.B.C. issued a strong declaration criticizing judges who delay sentences for the purposes of monitoring the success of a program of treatment and counselling undertaken by the offender. This was a case involving a major sexual assault by a father against a daughter. A suspended sentence, the court noted "fails to adequately express society's denunciation of the conduct...the shocking breach of trust inherent in [these] actions must be a particular concern. ${ }^{146}$ This case seems to suggest that a suspended sentence is not appropriate where major sexual assaults against children are involved.

Child sexual abuse committed by individuals in positions of public trust are clearly viewed as major sexual assaults. In making this determination, the Alberta Court of

See Rogers, supra note 1 at 12.

R. v. Blancard, [1992] B.C.J. No. 762 (Q.L.) (B.C.C.A.).

R. v. Kelly (1988), 68 Nfld. \& P.E.I.R. and 209 A.P.R. 236 (Nfld. C.A.).

$R$. v. Balraj S.S., supra note 10.

R. v. Richard, [1993] N.S.J. No. 68 (Q.L.) [hereinafter Richard].

R. v. Dejaeger, [1990] N.W.T.J. No. 44 (Q.L.) (N.W.T. S.C.).

R. v. A.B.C. (1992), 120 A.R. and 8 W.A.C. 106 at 110 (Alta. C.A.). 
Appeal in $R$. v. $S$. (W.B.); R. v. $P$. $(M .)^{47}$ has imposed a starting point sentence of four years. While this case did not involve religious figures, the principles outlined were clearly applied by the Court of Appeal some two months later in increasing the sentence of a religious figure charged with 15 counts of sexual assault committed against girls aged 12 to 17 over a five year period. The sentence was increased from $41 / 2$ to 8 years with the position of trust being considered a significant aggravating factor. As noted earlier, the Court of Appeal in an obiter comment, placed the blameworthiness of a religious leader who abuses trust at a higher level than that of a parent. ${ }^{48}$

The severity of sentencing of child sexual offenders generally is therefore attributable to the heinous nature of the crime, the shaping of public opinion by the media, ${ }^{49}$ and a desire by the courts to establish a pattern of sentencing that sets normal individuals apart from the deviant. ${ }^{50}$ In Alberta, at least, the courts appear to be placing religious figures, as individuals in a position of public trust, at a higher level than all other individuals including parents. The article will now address the sentencing of religious figures in the context of the important factors and principles that must be considered by the court.

\section{PRINCIPLES AND FACTORS IN SENTENCING}

As previously noted, the position of trust occupied by religious figures is a significant aggravating factor at sentencing. Other aggravating factors that frequently arise include the length of time over which the sexual assaults were committed against individuals; the number of charges; the nature of sexual and physical violence; and the threat of reprisals (i.e. demanding that victims not report the incident). There are also a number of mitigating factors which can reduce a sentence, including the presence of a guilty plea which enables the victims to not appear in court to testify, and the convicted person's level of community service.

It would be a major undertaking to classify each case in accordance with the aggravating and mitigating circumstances noted above. Furthermore, such a descriptive approach would not likely provide useful insights on the rationale and sentencing principles utilized by the courts in making their decisions. Accordingly, this article will focus on an assessment of the principles used in sentencing religious figures convicted of child sexual abuse.

In a bill recently introduced to Parliament, it was noted that the fundamental purpose of sentencing was to contribute to the "maintenance of a just, peaceful, and safe society by imposing just sanctions" that had one or more of the following objectives:

4h See R. v. Balraj S.S., supra note 10. Although decisions of courts in other provinces are not binding in other jurisdictions, it is important to note that the Alberta Court of Appeal was heavily influenced by the decision of Newfoundland courts in cases involving the Christian brothers at Mount Cashel. 
- $\quad$ "to denounce unlawful conduct" (denunciation);

- " to deter the offender and other persons from committing offences" (specific and general deterrence);

- $\quad$ "to separate offenders from society" (incapacitation);

- $\quad$ "to provide reparations for harm done to victims or to the community" (retribution);

- "to promote a sense of responsibility in the offenders, and the acknowledgement of the harm done to victims and to the community"; and

- $\quad$ "to assist in rehabilitating offenders." ${ }^{\text {51 }}$

The broad objectives reflected in the bill are consistent with the goals of sentencing (i.e. protection of the public, and respect for the law) which were identified in a report of the Canadian Sentencing Commission in 1987. ${ }^{52}$ To what extent have these objectives and goals of sentencing been realized when dealing with religious figures convicted of child sexual abuse?

\section{A. PRELIMINARY OBSERVATIONS - LIMITED USE OF VENGEANCE}

In answering the above question, some preliminary observations must be made on principles that are not important, but yet are commonly perceived by the public to be a central issue. It could be suggested, for example, that the shift in sentencing patterns for religious figures in providing for a virtual period of incarceration, is consistent with a retributivist line of thinking. This school of thought stresses the blameworthiness of the conduct. In contrast, a utilitarian approach, where the personality of the offender becomes a target for intervention, is considered less important. ${ }^{53}$

In assessing the current situation, it would appear that the courts in sentencing religious figures have not exclusively adhered to either the retributivist or utilitarian schools of thought. In other words, it would be too convenient to focus on some of the language used by judges in describing the offences committed, such as "abhorrent behaviour" or "heinous crime", and therefore conclude that the sentences imposed are based on retributivist principles. There is frequently a tendency to conclude that in the court's desire to denounce crime, they are doing so out of vengeance, and are therefore strict retributivists. This is not however borne out by many of the judgments. 
The Newfoundland Court of Appeal, operating in a province which has heard numerous sexual abuse cases involving religious figures, has clearly indicated that vengeance is not a factor in the sentencing process. The decision of the Court in $R$. v. Atkins has been cited in cases involving religious figures. In that case, Goodridge, C.J.N. concluded: ${ }^{54}$

...a sentence is designed to protect the public, not to abate its anger at a particular crime. As has frequently been said, protection is attained through a balance of deterrence and rehabilitation. Neither should overwhelm or negate the other. The proper balance will vary from case to case.

The support for the proposition that vengeance is not a factor in the sentencing of religious figures is also evident in Alberta decisions. ${ }^{55}$ Rather, Alberta courts see the principles of deterrence and denunciation to be of greater importance.

\section{B. DETERRENCE}

There are essentially two types of deterrence: (i) specific — designed to deter a specific offender from re-offending and (ii) general - which attempts to discourage potential offenders in society at large from offending.

In many of the cases involving religious figures, specific deterrence is not an issue. Many of the offenders are successfully rehabilitated and have left their respective religious orders to embark on a lifestyle of marrying and raising children. These individuals are not viewed as a threat to society, therefore minimizing the importance of specific deterrence. ${ }^{56}$ The behaviour of these individuals is perhaps best explained by a desire to exert substantial control over their victims and is not attributable to a sexual or psychological disorder. It could however be argued that specific deterrence is a factor for those religious figures who are not capable of undergoing successful rehabilitation owing to a psychological disorder such as homosexual paedophilia. Arguably, if this is a disease that cannot be treated, specific deterrence will still remain an important element in the sentencing process for these individuals. ${ }^{57}$

On the other hand, general deterrence is a prominent factor in the sentencing of religious figures convicted of child sexual abuse. ${ }^{58}$ The court's rationale for supporting general deterrence in such circumstances is not always clear. Some cases, notably $D e$ Jaeger, in the Northwest Territories, and Bennett, in Newfoundland, clearly refer to the

R. v. Atkins, (1988) 69 Nfld. \& P.E.I.R. and 211 A.P.R. 99 at 103 (Nfld. C.A.). This was not a case involving religious figures but is frequently cited as authority in that province for the sentencing of offenders committing major sexual assaults.

See Whyte, supra note 33. The court notes on p.7 that retribution is not a part of the sentencing process however the court must in addition to deterrence, express denunciation. See R. v. Burke (J) No. 4, [1991] 92 Nfld. \& P.E.I.R. and 287 A.P.R. 304 (Nfld. S.C.T.D.); R. v. Kenny, supra note 26 and $R$. v. Blancard, supra note 41. Montreal Gazette (21 January 1991) B1.

See $R$. v. S.(W.B.); R. v. P.(M.), supra note 47 at 549; Hickey, supra note 32 at $75 ;$ Monaghan, supra note 34 at 3; Richard, supra note 44 at 11-12; and $R$. v. Rooney (1991), 90 Nfld. \& P.E.I.R. and 280 A.P.R. 72 at 75 (Nfld. S.C.T.D.). 
celibate lifestyle of the priests as presenting an opportunity, or at least contributing to the potential illicit behaviour of the religious figures. ${ }^{59}$

This article does not attempt to resolve the debate on whether a celibate lifestyle contributes to a greater incidence of child sexual abuse by religious figures. There is insufficient data to establish a clear relationship. Indeed, there are many married individuals who have also committed sexual acts against children which would lead one to conclude there are other determining factors. There may, for example, be a propensity among all adults, whether clergy or otherwise, to abuse power and their position of trust.

The courts would nonetheless likely be aware of studies completed in the United States which estimate that over six percent of the over 54,000 priests in that country are sexually involved with minors. ${ }^{60}$ It would appear logical to infer that the courts, recognizing the propensity of religious figures to offend, given the right circumstances which they themselves can create (in light of their position), must be given a strong message to deter them from doing so. The certainty of the penalty (i.e. actual incarceration), and the negative public reaction associated with the commission of this offence is clearly the message which the court is attempting to convey using the deterrence principle.

\section{REHABILITATION OF THE OFFENDER}

It is generally considered that enhanced prospects for rehabilitation may act as a mitigating factor in reducing a sentence. The courts have however, expressed a reluctance to reduce sentences in cases of religious figures convicted of child sexual abuse on this ground. ${ }^{61}$

Courts of Appeal in at least two Canadian jurisdictions (Newfoundland and B.C.) have emphasized the rehabilitation of the offender at the expense of general deterrence. ${ }^{62}$ In all cases, the offender was determined to be a heterosexual paedophile capable of rehabilitation, as opposed to a homosexual paedophile, unlikely to succeed in rehabilitation. $^{63}$

$R$. v. Dejaeger, supra note 45 . The judge noted the difficult and lonely life of priests. $R$. v. Bennett, supra note 34 at 86 refers to expert evidence of a psychiatrist who concluded that the celibate lifestyle contributes to the problem of child sexual abuse.

Toronto Star (12 August 1990) A5. Also see Cruz, supra note 30 at 505, where the author notes that if you include those other than child sexual abusers, upwards to 23 percent of clergymen in the United States are engaged in sexual conduct with parishioners.

R. v. S.(W.B.); R. v. P.(M)., supra note 47; and Kenny, supra note 26.

R. v. Burton (1982), 40 Nfld. \& P.E.I.R. and 115 A.P.R. 195 (Nfld. C.A.). Sentence was reduced from 4 months to time served of 12 days.

R. v. Collins (1987), 62 Nfld. \& P.E.I.R. and 190 A.P.R. 279 (Nfld. C.A.). A 5 year sentence reduced to 2 years and $R$. v. Blancard, supra note 41 in which a sentence of 3 years was reduced to 1 year by the Court of Appeal in British Columbia.

Jason Berry's book discusses among other things issues related to paedophilia and the clergy. See J. Berry, Lead us not into Temptation, Catholic Priests and Sexual Abuse of Children (New York: Doubleday, 1992).

In contrast to heterosexual paedophilia, the B.C.C.A. in R. v. Noyes, [1991] B.C.J. No. 309 (Q.L.) upheld a declaration of the Court that this individual, a homosexual paedophile, was a dangerous 


\section{IMPACT ON THE VICTIM}

Much has been written on the extent to which the exploitation of young persons by religious figures has contributed to permanent long term psychological and emotional damage to victims. ${ }^{64}$

In the practice of sentencing, a determination by the court that the victims have been severely impacted is a significant aggravating factor increasing the severity of the punishment. Historically, the courts did not generally focus on victims. Rather, they looked at the perpetrator of the act to consider ways in which that individual might be helped. $^{65}$

Recently, courts across the country have made strong pronouncements in favour of victims who had been subjected to abuse as a child. The case of $R$. v. S. (W.B.); R. v. P. (M.) in Alberta is a good example. McDonald, J., conceded there is a "cardinal fact" that there is a "very real risk of very real harm to the child" from being subjected to abuse. He went on to say that this cardinal fact can be relied upon where there is no expert or non-expert evidence presented to the court. ${ }^{66}$ The court is therefore quite prepared to exercise its discretion in recognizing the impacts on the victim in the sentencing process.

In Newfoundland, prior to R. v. S. (W.B.); R. v. P. (M.), the courts adopted a similar line of reasoning. Cameron, J. in Burke for example, indicates that it "defies common sense" to suggest that victims are not impacted by child sexual abuse. ${ }^{67}$

The Church, for its part, and by its own admission, has never recognized or exercised its responsibilities to victims of child sexual abuse to the extent that the public desired. The Church in recent times has recognized that it has contributed to the problem by

offender. The protection of society figured prominently in this decision.

See for example, Cruz, supra note 30; Hughes Report, supra note 4 at 472-478; and S. Young, "Sexual Molestation Within America's Parishes and Congregations: Should the Church be thy Priests' Keeper?" (1989) 91 W. Va. L. Rev. 1097. Also see D. O'Brien, Suffer Little Children: An Autobiography of a Foster Child (St. John's Newfoundland: Breakwater, 1991). This book was written from the perspective of one of the victims of the Mount Cashel Orphanage at St. John's Newfoundland.

For an interesting Alberta perspective see T. Arnold, "How Sexually Abused Boys Grow Up to be Tormented Men" Edmonton Journal (28 March 1993) E1, E2. A number of the boys interviewed referred to how the judicial investigation and national attention given to the situation at the Mount Cashel Orphanage in Newfoundland gave them hope that the system might be able to respond and accept their problems as victims of child sexual abuse.

$R$. v. Thorne, supra note 26 at 314 ; and $R$. v. Noyes, supra note 63 . This was also the conclusion of a Roman Catholic Church Inquiry into the problem released in July, 1990. See the Report of the Archdiocesan Commission of Enquiry into the Sexual Abuse of Children by Members of the Clergy, Vols I-III submitted to the most Reverend Alphonsus L. Penney D.D. Archbishop of St. John's, June $1990 \mathrm{Vol}$ I at 138. Also see "Help the Abused, Not Abusers, Victims Tell Bishop's Committee" Edmonton Journal (14 November 1993) AS. This article involved a request by a number of alleged victims of sexual abuse by priests in the United States to a committee of Catholic bishops established by the Church to look into the problem. 
sheltering its clergy and thereby making them less accountable for their conduct. They describe their own actions as attempting to settle a moral problem behind a veil of secrecy. ${ }^{68}$ The Church's renewed commitment to victims is perhaps best reflected in the following statement: ${ }^{69}$

We are convinced that pastoral care for the victims of sexual abuse consists above all in compassion, justice and healing of a grave injury inflicted upon those powerless to protect or defend themselves.

The position of the Roman Catholic Church is consistent with that taken by the Supreme Court of Canada, and in particular, by McLachlin, J., in noting that a position of trust is established when there is an imbalance of power and the potential for interference with a legal or non-legal interest of "vital and substantial practical interest. ${ }^{170}$

\section{SUMMARY AND CONCLUSIONS}

This article has addressed the sentencing considerations of courts when religious figures are convicted of child sexual abuse. The problem has taken on national significance. Although the more high profile cases have occurred in Newfoundland and Ontario, few jurisdictions have escaped substantial increases in the reporting of what the public views as a "heinous crime."

A significant aggravating factor considered by the court is the serious breach of trust committed by the religious figures. This trust involves situations where there is unequal bargaining power and a significant threat to the individual's legal and non-legal interests. The breach is arguably even more significant when one considers the secular trust that has been violated. Individuals as a result have generally felt a sense of alienation from the Church which has placed that institution in much lower public esteem.

The gravity of the problem has resulted in the courts imposing substantial periods of incarceration. This is in stark contrast to the former situation where more lenient dispositions, such as a suspended sentence with probation were acceptable when there were isolated incidents. The shift in sentencing patterns clearly reflects the desire to impose sentences that deter individuals and denounce the crime.

While this article has not dealt with imposing criminal responsibility and sanctions against the church for its role in perpetrating crimes against the children, it should be recognized that the issue has been addressed elsewhere. ${ }^{71}$

68 Canadian Conference of Catholic Bishops, supra note 8 at 41.

(y) Ibid. at 26-27.

no Norberg v. Wynrib, supra note 27 at 501.

7 See D. Russell, "Paedophilia: The Criminal Responsibility of Canada's Churches" (Fall 1992) $15: 2$ Dalhousie L.J. 380 at 407 in which the author notes that one of the reasons for imposing criminal liability on the church is "to initiate organizational changes on internal disciplinary procedures, or to modify or introduce preventative policies and procedures." 
Public sentiments have been shaped to a large extent by the apparent reluctance, at least from an historical perspective, by the Church to accept its full responsibility for victims suffering damages as a result of child sexual abuse. The Church, as this article observes, is more prepared to accept this responsibility today. ${ }^{72}$

The needs of the victims are now better reflected in the sentencing process. Some courts appear to accept as a "cardinal fact" that long term psychological and emotional damage is inevitable from sexual abuse. Furthermore, the courts in some jurisdictions, notably Alberta, no longer require expert or non-expert evidence to substantiate this claim.

There is a very real possibility that sympathy for the victims will remain a cornerstone of future decisions involving child sexual abuse. At the time of writing, the Supreme Court of Canada made an important decision concerning the need to relax time limits imposed by Statute when filing a civil action for damages sustained as a result of incestuous sexual conduct by a parent. ${ }^{73}$ The potential for severe financial penalties to the perpetrator and the increased profile given by the media to cases of this nature may act as a deterrence to future crime.

\section{A. FUTURE SENTENCING PATTERNS FOR RELIGIOUS FIGURES - CHILD SEXUAL ABUSE GENERALLY}

One can only speculate as to how the courts might decide future cases involving religious figures convicted of child sexual abuse. If we accept the view that the cases to date represent only "the tip of the iceberg," then the factors and principles shaping

See Globe and Mail (4 April 1992) A1. Mount Cashel has been torn down and a Mount Cashel orphanage trust fund has been established for children in need. The objects of the trust are "to provide for persons with no living parent, young persons with only one parent, young persons with parents not capable of providing the basic needs of care, maintenance and education ... and any other persons deemed in need pursuant to the aims and objects of the trust." This information was obtained in an affidavit of Brother Timothy Turner in the case Canada Trust Co. v. St. Patrick's Mercy Home, [1992] N.J. No. 122 (QL) (Nild. S.C.T.D.).

See Toromo Star (14 August 1992) A3 and Globe and Mail (14 August 1992) for a description of the settlement reached with victims in Ontario. Essentially a $\$ 16.1$ million settlement was concluded with one-third to be paid by the Province, and the balance to be paid by the schools involved and by the archdioceses of Toronto and Ottawa. It is interesting to note that insurance companies have publicly disclosed that they are considering riders in policies covering churches to protect themselves from liability in sexual molestation claims. See E. Clifford, "Insurers Fear Church Risk" Globe and Mail (24 January 1994) B1, B2.

K.M. v. H.M., [1992] 3 S.C.R 6. Shortly following this decision an Ontario court ordered a father to pay $\$ 500,000$ and interest in damages to his daughter for sexual abuse which occurred over a period of 11 years. See P.B. v. W.B., [1992] O.J. No. 2538 (Q.L.) (Ont. Court of Justice General Division). For an overview of this emerging legal issue see N. Des Rosiers, "Limitation Periods and Civil Remedies for Childhood Sexual Abuse" (1992) 9 C.F.L.Q. 42.

It is also interesting to note that a $\$ 1.5$ billion class action suit was recently commenced in Quebec by residents of an orphanage against the Sisters of Charity and the Quebec Government for alleged physical, sexual, and psychological abuse suffered in the 1940s to 1960s. See J. Branswell, "Orphans Sue Nuns, Quebec Government" Edmonton Journal (12 March 1993) A1. A request of the Quebec government to help finance the class action has since been denied. See "Government Rejects Aid for Duplessis Orphans Suit" Edmonton Journal (14 November 1993) A4. 
sentencing, notably deterrence, denunciation, and support for the victim will remain important, and will likely result in the continuation of harsh sentences in the form of incarceration. ${ }^{74}$ If on the other hand, the principles that have been employed in recent years have achieved their objectives of protecting society and maintaining law and order, then we may see the courts being prepared to revert to less harsh measures. This I submit is an unlikely scenario since the offence of child sexual abuse is still considered a major sexual assault, and the mistrust that has permeated society, in particular between the Church and the individual, will require considerable time to heal. I believe the church has not yet sufficiently empowered individuals to effect the needed changes to the institution in order to instill greater public confidence. As a consequence, the Church may still be viewed by many as an oppressive institution with an imbalanced power structure remaining intact.

Finally, there is a suggestion that support for victims may not be occurring fast enough and a large part of the blame must be placed on government decisions to maintain its policy of incarcerating individuals at a great expense to society. Some would suggest that monies be reprofiled from the prison system to enhanced program support for child abuse victims. ${ }^{75}$ In this context it is important to note that the Federal Minister of Justice, when introducing recent amendments to the Criminal Code affecting sentencing, emphasized that prison was to be used as a measure of last resort. ${ }^{76}$

The Minister was not clear however on which offences legislators would prefer to deal with outside of incarceration. It could be argued based on other initiatives of Parliament in recent months that sexual offences against children would not represent an offence where prison is considered a last resort measure. One such initiative is the passage of the Corrections and Conditional Release $\mathrm{Act}^{77}$ which may require high risk child sex abusers to serve their full sentence. This action demonstrates the seriousness that Parliament attaches to this offence.

Furthermore, former Solicitor General Doug Lewis recently indicated that consideration is being given to broadening the dangerous offender provisions in the Criminal Code (s. 753) and using mental disorder provisions of the code to keep sexual offenders in jail long after their sentence expires. ${ }^{78}$

See G. Whiffen, "More Charges laid against Christian Brothers Serving Time in Mount Cashel Abuse Scandal" Evening Telegram (1 June 1993) 6.

See also "Men Charge Priests Planned Child Sex Ring" Evening Telegram (11 June 1993) 8 in reference to a class action lawsuit in New Jersey in what is believed to be the first class action suit involving sexual abuse by priests filed under racquetering statutes. See L.M.G. Clark, "Feminist Perspectives on Violence Against Women and Children: Psychological, Social Service, and Criminal Justice Concerns" (1989-90) 3 C.J.W.L. 420. S. Bindman, "Use Prison as Last Resort, New Criminal Code Says" Toronto Star (24 June 1992) A5. S.C. 1992, c. 20. Also see B. Cox, "Crime Issues Are Expected to be Front and Centre in Federal Election" Evening Telegram (26 May 1993) 4. N. Ovenden, "Anxious Public Forcing MP's to Get Tough on Crime" Edmonton Journal (5 December 1992) E1.

For the mental health provisions see Bill C-30, An Act to Amend the Criminal Code (Mental Disorder), 3d Sess., 34th Parl., 1991-92 (assented to 13 December 1991). For an excellent overview of this important piece of legislation see (1992) 1:2 Health L.R. 1. 
The former Federal Solicitor General also commissioned an advisory panel to recommend measures to protect the public from offenders considered likely to repeat violent crimes which includes child sexual abuse. That panel recently recommended that the dangerous offender provisions of the Criminal Code be used more extensively to incarcerate child sexual abusers for an indefinite period. ${ }^{79} \mathrm{Mr}$. Lewis is also on record as being prepared to consider a sexual predator law that would in effect allow for a trial before the conclusion of a sexual offenders sentence, with a view to determining whether the period of incarceration should be increased. ${ }^{80}$

It would appear that the legislative changes to date together with the recent pronouncements serve as indication that the commission of major sexual assaults against children will warrant stiff penal sanctions. This may serve the public interest and in particular the concerns of numerous innocent victims of these sexual offences. While the pain and suffering cannot be forgotten, the victims can take solace in the fact that after considerable waiting, access to justice has at least been partially achieved. is however likely to be subject to a constitutional challenge, largely on the basis of a lack of due process, if it was done arbitrarily by government. 